\title{
Threatened Woody Plant Species and Factor of Threat in Adjacent Area of Babile Elephant Sanctuary, Eastern Hararghe, Ethiopia
}

\author{
Abdurazak Sufiyan", Tahir Abdala \\ Ethiopian Biodiversity Institute, Harar Biodiversity Centre, Harar, Ethiopia \\ Email address: \\ zakoahmado@gmail.com (A. Sufiyan) \\ ${ }^{*}$ Corresponding author
}

To cite this article:

Abdurazak Sufiyan, Tahir Abdala. Assessment of Threatened Woody Plant Species and Factor of Threat in Adjacent Area of Babile Elephant Sanctuary, Eastern Hararghe, Ethiopia. American Journal of BioScience. Vol. 9, No. 5, 2021, pp. 153-161. doi: 10.11648/j.ajbio.20210905.11

Received: September 5, 2021; Accepted: September 22, 2021; Published: October 5, 2021

\begin{abstract}
Protected areas plays important role in conservation of biological diversity. Assessment of threatened plant species and factor associated with this threat is of immense importance in managing protected area. This study was conducted on around Babile Elephant Sanctuary buffer zone located. This study aimed at documenting threatened plant species, factors of threat and challenges around BES. The data were collected from total number of informants 96 using semi-structured questionnaire, observation and guided field walks. The result of the assessment revealed a total of 61 threatened plant species among these 30 were shrub, 28 Tree, 2 climber and 1 herb and were represented by 25 families and 47 genera. Fabaceae, Tiliaceae, and Capparidaceae were the three dominant plant species respectively and each comprise 12, 4, and 3 species respectively. Regarding level of threatened plant species, 38 (45.7\%) species were categorized under highly threatened, $23(38 \%)$ species were categorized under medium threatened and $10(16 \%)$ species were categorized under low/least threatened. The response of informants from six kebele suggested that the presence of ten factors which were exposing highler threat level on BES. Top three factors that threaten plant species includes agricultural expansion, illegal settlement, and Charcoal which accounts for $97.9 \%, 81.25 \%$, and $62.5 \%$ respectively. Eight major challenges were identified for current conservation BES. Lack of alternative job as the major challenge as responded by communities 90 (93.75\%) followed by Lack of community Incentive when elephant browsing and damage local crop $87(90.62 \%)$ and Lack of strong regulation and relation of park administration with community was the third factor as responded by $85(88.54 \%)$. The current study suggest that important intervention is necessary to conserve threatened plant species in BES.
\end{abstract}

Keywords: Diversity, Eastern Hararghe, Ethiopia, Challenge, Threat

\section{Introduction}

Establishment of protected areas is vital for in situ conservation of diverse native species. Protected areas play a major role in the conservation of biodiversity [24, 23]. Traditionally, protected areas have been established to safeguard important landscapes and seascapes, major species, and their habitats $[12,36]$. In the last few decades, there has been a major increase in conservation areas to reduce biodiversity loss and enhance ecosystem integrity, function, and services [18]. Moreover, there is the Convention on Biological Diversity (CBD) of Aichi Biodiversity Target 11 to make $17 \%$ of the terrestrial surface and $10 \%$ of the marine realm ecosystem into the protected area by 2020 [8]. These activities are undertaken for the purpose of education, research, and recreation. Moreover, these areas provide such essential items as fuel wood, building materials, forage, traditional medicines and wild foods.

Currently, the amount of area assigned as protected area globally is 17 million $\mathrm{km}^{2}$ (12.7\% of the land surface) and 6 million $\mathrm{km}^{2}$ (1.6\% of the marine surface) [8]. However, extra land to set aside for conservation of biodiversity are challenged by the globally rising demand for food and other purposes, creating trade-offs between areas dedicated to biodiversity conservation versus agriculture $[5,26]$. Therefore, there is a need to find an optimal balance between 
conservation and development especially in developing countries, where addressing widespread food insecurity and poverty is a regional priority.

In Ethiopia, protected areas cover approximately $16.4 \%$ of the country's surface area $[32,36]$. There are 20 national parks, 3 sanctuaries, 2 wildlife reserves and 17 controlled hunting areas, 7 open hunting areas and 3 community conservation areas covering an area of about $65,531.4 \mathrm{~km}^{2}$ [13]. However, except few, most of the protected areas exist on paper only and have declined in size and quality.

Protected areas have hardly been managed in Ethiopia due to population pressures $[25,11,35]$. Often, the decision made on protected areas do not take due consideration of the interest of stakeholders, especially communities who are dependent on the local resources [36]. As a result, uncontrolled expansion of agriculture and grazing coupled with illegal harvesting of vegetation and other products have been threatening the function of the protected area system in many parts of the country [37, 21]. Furthermore, overgrazing is exposing the land for severe erosion and retarding the recruitment and survival of tree seedling [20]. Lack of integration of the livelihood of the local people living around BES and the absence of law enforcement system are the major constraints to the overall conservation efforts.

The knowledge of the factors involved in the deterioration of the ecosystems found inside protection areas are fundamental for appropriate management. Disturbances can lead to vegetation degradation and subsequent reduction of desirable characteristics of an area for nature conservation [2, 6]. Babile Elephant Sanctuary (BES) is one of the protected areas in the semi-arid region of eastern Ethiopia, which has highly declined in size and quality $[3,10,33]$. The sanctuary was established to protect the only known population of the isolated and ecologically distinct subspecies Loxodonta africana orleansi [7]. Recent socio-economic and land use changes in BES such as the demand for more area for agriculture have reduced the woodland area, increasing the severity of impact both humans and elephants have on woody vegetation. Erer Valley, which is the largest part of the Babile Elephant Sanctuary. This valley is the most extensive part of the sanctuary where it is currently subject to increasing settlement pressure from all buffer zone since it had high prize of underground. Both the human and livestock population have increased dramatically [3]. Highly dependent of local community on vegetation's for fencing, medicine, construction, temporary settlement, charcoal and fuel wood for subsistence daily livelihood. At the same time, large mammals such as the African elephant selectively utilize the woody vegetation's, capable of affecting the vegetation of the region they inhabit [28]. More over currently this existence of high prize of underground water become increasing agricultural investment around buffer zone and the computation expansion boundary between Ethio-Somale and Oromiya woreda around buffer zone subject for deterioration of protected area. So, this study was aimed to assess threatened woody plant species, factor of threat, and challenges around buffer zone of BES which is critical in developing action plans that will restore sustainable utilization of plant resources on the sanctuary.

\section{Materials and Methods}

\subsection{Description of Study Area}

Babile Elephant Sanctuary (BES), in the eastern lowlands of Ethiopia, is part of the Somali-Masai centre of endemism [7]. The underlying rocks are mainly marine in origin and soils are characterized by cambisols, luvisols, nitosols, orthic solonchakes, fluvisols, vertisols and xerosols [22]. The sanctuary is situated at the semi-arid trans-boundary of Oromia and Somali Regions, at about $560 \mathrm{~km}$ from Addis Ababa. It is delimited with coordinates of latitudes $08^{\circ} 22^{\prime} 30^{\prime \prime}$

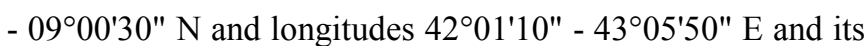
elevations ranges between 850 and 1,785 $\mathrm{m}$ a.s.1. [27, 34].

When the sanctuary was established in 1970, it covered an area of about $6,984 \mathrm{~km}^{2}[27,14]$ between the Eastern Hararge high mountain i.e. Mt. Gara- Muleta to the west and the Ogaden Desert to the southeast. Four main drainage river valleys (Fafem, Daketa, Erer and Gobelle) rise from Garamuleta-Harar-Gursum Highlands and extend southwards through the sanctuary to join Wabi Shebelle River Basin (Figure 1).

\subsection{Flora and Fauna}

The vegetation of the sanctuary was represented by Acacia-Commiphora woodland, semi-desert scrubland and evergreen scrub ecosystems [27]. More recent data indicated that the riverine species in the upper Erer Valley are comprised of Acacia robusta Burch. Tamarindus indica L., Oncoba spinosa Forssk. Acokanthera schimperi (A. DC.) Schweinf. and Capparis tomentosa Lam. (Anteneh Belayneh, 2006). The Sanctuary is prized for hosting species of interest like the African elephant, Black-manned lion, Leopard, Hamadryas baboon and Menelik's Bushbuck, the only endemic subspecies for the sanctuary. Based on a direct count, [35] had reported the presence of about 324 elephants in the sanctuary with indications that the number could rise to 400 .

\subsection{Climate}

The BES is generally characterized by semi-arid climatic condition. The mean annual temperature is about $19.6^{\circ} \mathrm{C}$, ranging from a mean minimum of $11.9^{\circ} \mathrm{C}$ to mean maximum of $27.2^{\circ} \mathrm{C}$. There is only a slight difference in temperature throughout the year, with the hottest months in April to June (maximum $29^{\circ} \mathrm{C}$ ) and the coldest months during October to December (minimum $7.8^{\circ} \mathrm{C}$ ). The mean annual rainfall is $702.9 \mathrm{~mm}$ year-1, with high variation from year to year, ranging from 451.7 to $1,115.9 \mathrm{~mm}$ year-1. Rainfall is bimodal occurring from March to April (short rain season) and June to September (long rain season) (source: [4]).

\subsection{Sampling and Sampling Design}

The study was conducted on around Babile Elephant Sanctoury buffer zone located in two region of Ethiopia 
namely Ethio-Somale and Oromia region which border the BES. Accordingly, purposive sampling method were employed to select six kebele from the two region for data collection purpose. Among the six kebele two kebele were from Ethio-Somale Babile Woreda includes Dendema and Biqo kebele and the other four kebele were from Oromiya region Babile woreda include Erer Ebada, Ibada Gamachu, and from Fedis woreda Riski and Aneni.

A total of 10 informants were selected randomly and 6 key informants were selected purposively from each kebele with total number of informants 96 were selected following [19].

\subsection{Data Collection Methods}

Data were collected from both primary and secondary data. Primary data were collected through Semi-structured interview, focus group discussions, and guided field walks with informants were employed following [19, 1, 9] and field observation was carried out with local field guide assistant who have the skill of local language. Secondary data were collected from BES office, Ethio-somale Babile woreda and Babile and Fedis woreda from Oromia region and publish and unpolished literature survey. During formal and informal interview the respondents we requested to categorize level threat for all of the forest species into three categories: High, Medium and low. Where 'High' represent highly threatened plant species, when the population of the plant is rare and declining in the study area. Where 'medium' represent near threatened plant species, when the population of plant species some was present but, not much abundant generation. Where 'low' represent least threatened plant species, when the population of plant species has good regeneration. To help the respondents to categorize the species key questions like trends of plant species, the origin of plant species and importance of individual species were asked.

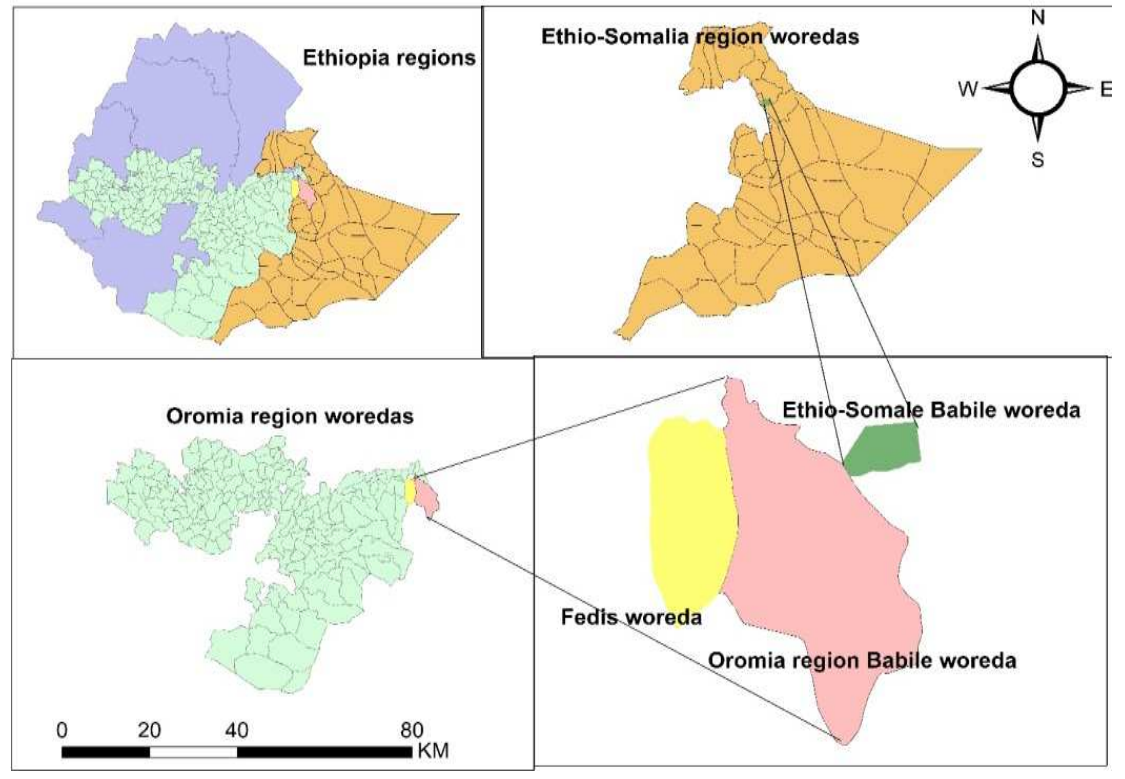

Figure 1. Map of study area (By: Abdurazak Sufiyan).

Table 1. Location of sampling.

\begin{tabular}{lllll}
\hline \multirow{2}{*}{ No } & Name of & Location & \multicolumn{2}{l}{ Altitude } \\
\cline { 3 - 5 } & sampling site & Latitude $(\mathbf{N})$ & \multicolumn{3}{l}{ Longitude $(\mathbf{E})$} \\
\hline 1 & Erer ibada & 42.25228 & 9.12095 & 1,274 \\
2 & Ibada gamachu & 42.25228 & 9.12095 & 1,274 \\
3 & Riski & 42.03472 & 9.04000 & 1,500 \\
4 & Aneni & 42.04750 & 8.98556 & 1,556 \\
5 & Biqo & 42.37584 & 9.05277 & 1,415 \\
6 & Dendema & 42.39151 & 8.93193 & 1,462 \\
\hline
\end{tabular}
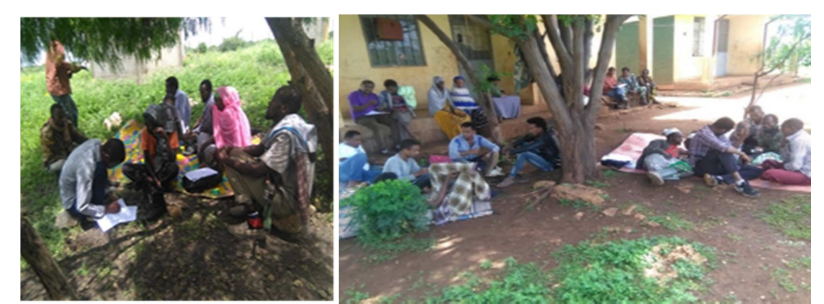

Figure 2. Researcher discus with focal person and local community (photo: by Tahir Abdala).

\subsection{Data Analysis}

The collected data entered into Excel spreadsheet 2007 and summarized by Descriptive statistics like table, percentage and graph. Preference ranking and paired comparison were computed following [1] to analysis factor threatened woody plant species and most threatened plant species.

\section{Result and Discussion}

\subsection{Diversity and Status of Threatened Plant Species}

The result of the assessment revealed a total of 61 threatened plant species as shown in (Table 2). Among this 30 were shrub, 28 Tree, 2 climber and 1 herb as indicated in (figure 4) and were represented by 25 families and 47 genera. Fabaceae, Tiliaceae, and Capparidaceae were the three dominant plant species respectively and each comprise 12, 4, and 3 species respectively. Eight family 
include two species each those were Rhamnaceae, Balanitaceae, Boraginaceae, Burseraceae, Apocynaceae, combretaceae, sapindaceae and euphorbiaceae and the other plant families were only represented by a single species. The genus Acacia and Grewia were represented by 10 and 4 species respectively while genus Balanite and genus Commiphora were represented by 2 species each. Other genera were only represented by one species each as indicated in (Table 2). The list of all surveyed threatened plant species around BES was shown in Table 2 and the dominant family of threatened plant species around BES was shown in figure 3. This study was supported by review made on floristic diversity and threated plant species in Babile Elephant Sanctuary [30] and also with assessment made on forest biodiversity resources and level of threat in Hararge Area [29].

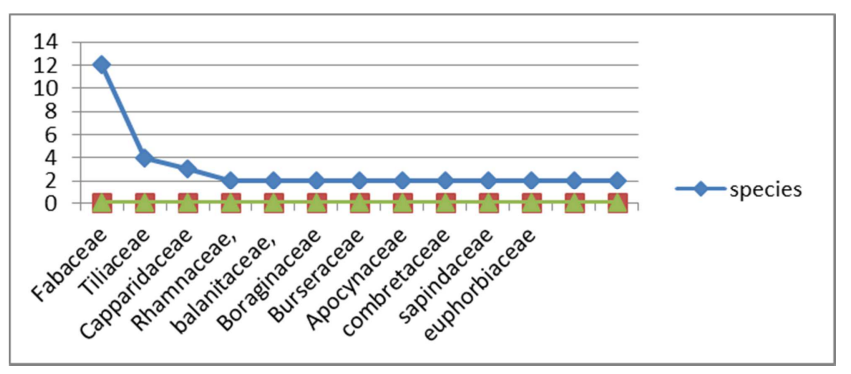

Figure 3. Dominant family plant species around BES

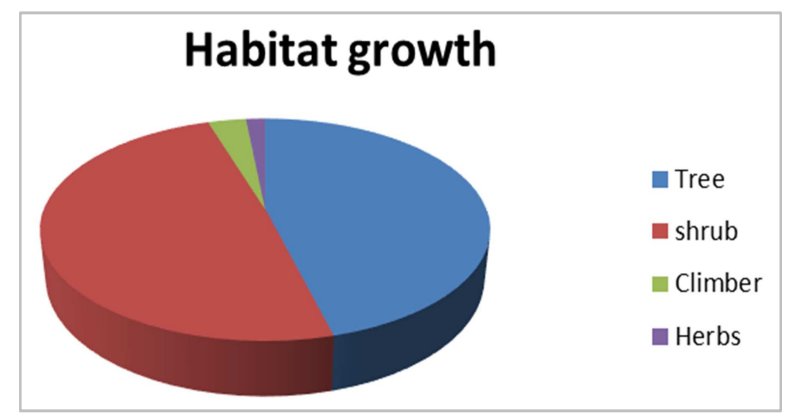

Figure 4. Growth habit of threatened plant species.

As shown in the Table 2, 61 total number of threatened plant species were identified from respondents. The identified threatened plant species and their level of threat were determined by knowledge of local community. Regarding level of threatened plant species, $38(45.7 \%)$ species were categorized under highly threatened, 23 (38\%) species were categorized under medium threatened and $10(16 \%)$ species were categorized under low/least threatened.

\subsection{Factors of Threats to Plant Species Around BES}

According to (Table 3) and (figure 5), the response of informants from six kebele suggested that the presence of ten factors which were exposing highler threat level on BES. Among them, agricultural expansion was become highly threat the park and score $97.9 \%$ followed by illegal settlement $81.25 \%$. and also Charcoal was the $3^{\text {rd }}$ factors currently targeted accounting $62.5 \%$ and invasive scored $60.4 \%$ followed by investment and selective cut for construction (59.37\%), Elephant browsing (46.87\%), fire wood $(43.75 \%)$, drought $(41.66 \%)$, and Honey collection (16.6\%). This finding was similar to [4] and it is also supported by [16] in which most of the threatened protected areas such as natural forests and mountainous ecosystem protected areas have been degraded through livestock grazing and deforestation. The result obtained from Abijata-Shalla National Park of Ethiopia was also similar to this study [17]. According to this study, excessive exploitation of natural resource by human was the main reason for changing the park habitat. Threats to wildlife and their habitat was increased due to subsequent increase in human activity [31, 15]. According to [17], human activities caused threats to biological resources through competition with wildlife, deterioration of their habitats and environmental degradation.

\subsection{Current Challenges of BES Conservation}

The survey revealed that Lack of alternative job 90 (93.75\%), Lack of community Incentive when elephant browsing and damage local crop 87 (90.62\%), and Lack of strong regulation and relation of park administration with community 85 (88.54\%) were the three top factor that caused the threats responded by communities. The other challenges including Lack of Awareness, Lack of community participation for conservation, Dependence of local community on agriculture, Existence of park between two region, and Lack of clear boundary demarcate accounts for $80(83.33 \%), 76$ (79.1\%), 68 (70.83\%), 65 (67.70\%), and 57 $(59.37 \%)$ respectively. Table 4 shows that not only community related factor are causing the factor but also management bodies contribute for biological resource depilation. This indicate that lack of cooperation, integration, and collaboration between communities and management bodies in conservation of biological resources of the sanctuary. Lack of cooperation and coordination among stakeholders minimize the success of conservation activities [16, 21, 15]. Participation of communities on decision making process may be necessary so that they perceive the own the resource otherwise conservation of biological resources is unsuccessful [16].

Table 2. List of threatened plant species around BES buffer zone.

\begin{tabular}{llllll}
\hline No & Scientific name & Family name & Local name & Growth habitat & Status \\
\hline 1 & Acacia albida & Fabaceae & Garbi & T & High \\
2 & Acacia brevispica & Fabaceae & Hamareysa & S & High \\
3 & Acacia bussei & Fabaceae & Halloo (Or) & T & High \\
4 & Acacia mellifera & Fabaceae & Bilaila (Or) & S & Medium \\
5 & Acacia nilotica & Fabaceae & Serkema & S & Medium \\
6 & Acacia oerfota & Fabaceae & Ajoo & S & Medium \\
7 & Acacia robusta & Fabaceae & Wangeyoo & T & Medium \\
\hline
\end{tabular}




\begin{tabular}{|c|c|c|c|c|c|}
\hline No & Scientific name & Family name & Local name & Growth habitat & Status \\
\hline 1 & Acacia albida & Fabaceae & Garbi & $\mathrm{T}$ & High \\
\hline 8 & Acacia Senegal & Fabaceae & Soppensa & S & Medium \\
\hline 9 & Acacia seyal & Fabaceae & Wachu & $\mathrm{T}$ & Medium \\
\hline 10 & Acacia tortilis & Fabaceae & Dhadacha & $\mathrm{T}$ & High \\
\hline 11 & Acokanthera schimperi & Appocynacee & Qaraaru & $\mathrm{T}$ & High \\
\hline 12 & Aloe pirottae & Aloaceae & Hargeysa & S & Medium \\
\hline 13 & Allophylus rubifolius & Sapindaceae & & $\mathrm{H}$ & High \\
\hline 14 & Azadirachta indica & Meliaceae & Kinina & $\mathrm{T}$ & Low \\
\hline 15 & Bascia minimifolia & Capparidaceae & Meygag & $\mathrm{T}$ & Medium \\
\hline 16 & Balanites aegyptiaca & Balanitaceae & Bedeno & $\mathrm{T}$ & Medium \\
\hline 17 & Balanites glabra & Balanitaceae & Kutka & $\mathrm{T}$ & High \\
\hline 18 & Barleria hildebrandtii & Acanthaceae & Dhaallaa & S & High \\
\hline 19 & Berchemia discolor & Rhamnaceae & Jajeba & $\mathrm{T}$ & High \\
\hline 20 & Cadaba farinose & Capparidaceae & Kelkelcha & S & High \\
\hline 21 & Combretum molle & Combretaceae & Rukkeysa & $\mathrm{T}$ & High \\
\hline 22 & Commiphora erythrae & Burseraceae & Kedhon (S) & $\mathrm{T}$ & Medium \\
\hline 23 & Commiphora schimperi & Burseraceae & Dekero & $\mathrm{T}$ & High \\
\hline 24 & Capparis tomentosa & Capparidaceae & Gamoora & $\mathrm{C}$ & High \\
\hline 25 & Carissa edulis & Apocynaceae & Agamsa & S & Low \\
\hline 26 & Cordia monoica & Boraginaceae & Medhero & S & Low \\
\hline 27 & Celtis africana & Ulmaceae & Mataqooma & $\mathrm{T}$ & Medium \\
\hline 28 & Cussonia holstii & Araliaceae & Harfattuu & $\mathrm{T}$ & High \\
\hline 29 & Dodonaea angustifolia & Sapindaceae & Edechaa & S & Medium \\
\hline 30 & Dichrostachys cinerea & Fabaceae & Jirime & S & Medium \\
\hline 31 & Ehretia cymosa & Boraginaceae & Huulaga & $\mathrm{T}$ & Medium \\
\hline 32 & Euclea racemosa & Ebenaceae & Mi'esaa & S & High \\
\hline 33 & Euphorbia burger & Euphorbiaceae & Hadami & S & Medium \\
\hline 34 & Ficus thonningii & Moraceae & Dambii & $\mathrm{T}$ & Medium \\
\hline 35 & Flacourtia indica & Flacourtiaceae & Hudhaa & S & Medium \\
\hline 36 & Flueggea virosa & Euphorbiaceae & Kechachile & S & High \\
\hline 37 & Grewia bicolor & Tiliaceae & Haroresa, & $\mathrm{T}$ & Low \\
\hline 38 & Grewia ferruginea & Tiliaceae & Bururi, Ogemdi & $\mathrm{T}$ & High \\
\hline 39 & Grewia kakothamos & Tiliaceae & Midhayoo & S & Low \\
\hline 40 & Grewia schweinfurthii & Tiliaceae & Mudhugurre & $\mathrm{S}$ & Medium \\
\hline 41 & Grewia villosa & Tiliaceae & Ogomoodi & S & Low \\
\hline 42 & Justcia schimperiana & Acanthaceae & Dhumugaa & S & Low \\
\hline 43 & Kirkia tenuifolia & Simaroubaceae & HudhaaSawwa & S & High \\
\hline 44 & Kleinia squarrosa & Acanthaceae & & S & Medium \\
\hline 45 & Lannea schimperi & Anacardiaceae & Handarakkuu & $\mathrm{T}$ & Medium \\
\hline 46 & Olea europaea & Oleaceae & Ijersa & $\mathrm{T}$ & High \\
\hline 47 & Oncoba spinosa & Flacourtiaceae & Jilboo & S & High \\
\hline 48 & Opuntia ficus-indica & Cactaceae & Tiini & S & Low \\
\hline 49 & Ozoroa insignis & Anacardiaceae & Rukeylu & $\mathrm{T}$ & Medium \\
\hline
\end{tabular}

Table 3. List of threatened plant species around BES buffer zone.

\begin{tabular}{llllll}
\hline No & Scientific name & Family name & Local name & Growth habitat & Status \\
\hline 50 & Premna oligotricha & Lamiaceae & Urgessaa & $\mathrm{S}$ & Medium \\
51 & Plectranthus cylinderaceus & Lamiaceae & Barbarisha & & S \\
52 & Rhoicissus revoilii & Vitaceae & & C & Low \\
53 & Rhus natalensis & Anacardiaceae & Laalu & S & High \\
54 & Sterculia Africana & Sterculiaceae & Dobobeeysaa & $\mathrm{T}$ & Low \\
55 & Salvadora persica & Salvadoraceae & Geri & $\mathrm{T}$ & Medium \\
56 & Tamarindus indica & Fabaceae & Ade & $\mathrm{T}$ & High \\
57 & Terminalia brownie & Combretaceae & Roka & $\mathrm{T}$ & High \\
58 & Withania & Solanaceae & Bireysaa & $\mathrm{S}$ & High \\
59 & Somnifera & Rhaminaceae & Hidi gudeye & $\mathrm{T}$ & High \\
60 & Ziziphus spina & Rhaminaceae & Kurkura & T & High \\
61 & Ziziphus mucronata & Rutaceae & Kurkura gabbro & & High \\
\hline
\end{tabular}


Table 4. Factors of threats Cited By respondent from the sample of six kebele $(N=96)$.

\begin{tabular}{|c|c|c|c|c|c|c|c|c|c|c|}
\hline \multirow{2}{*}{ NO. } & \multirow{2}{*}{ Factors Of Threat } & \multicolumn{6}{|c|}{ Kebele Of Respondent } & \multirow{2}{*}{$\begin{array}{l}\text { Total } \\
\text { Respondent }\end{array}$} & \multirow{2}{*}{$\begin{array}{l}\% \text { of } \\
\text { (R) }\end{array}$} & \multirow{2}{*}{ Rank } \\
\hline & & Dendema & Erer Ibada & Riski & Ibada gamachu & Aneni & Biqo & & & \\
\hline 1 & Agricultural Expansion & 16 & 17 & 19 & 19 & 11 & 12 & 94 & 97.9 & 1 \\
\hline 2 & Illegal settlement & 12 & 11 & 16 & 14 & 15 & 10 & 78 & 81.25 & 2 \\
\hline 3 & Investment & 10 & 15 & 8 & 8 & 11 & 5 & 57 & 59.37 & 5 \\
\hline 4 & Charcoal & 12 & 9 & 7 & 7 & 10 & 15 & 60 & 62.5 & 3 \\
\hline 5 & Elephant browsing & 5 & 5 & 5 & 9 & 7 & 14 & 45 & 46.87 & 6 \\
\hline 6 & Invasive & 9 & 7 & 6 & 12 & 14 & 10 & 58 & 60.4 & 4 \\
\hline 7 & Drought & 13 & 4 & 4 & 4 & 9 & 6 & 40 & 41.66 & 8 \\
\hline 8 & selective cut for Construction & 10 & 8 & 4 & 13 & 13 & 9 & 57 & 59.37 & 5 \\
\hline 9 & Firewood & 8 & 4 & 5 & 11 & 3 & 11 & 42 & 43.75 & 7 \\
\hline 10 & Honey collection & 3 & 3 & 3 & 5 & 1 & 1 & 16 & 16.6 & 9 \\
\hline
\end{tabular}

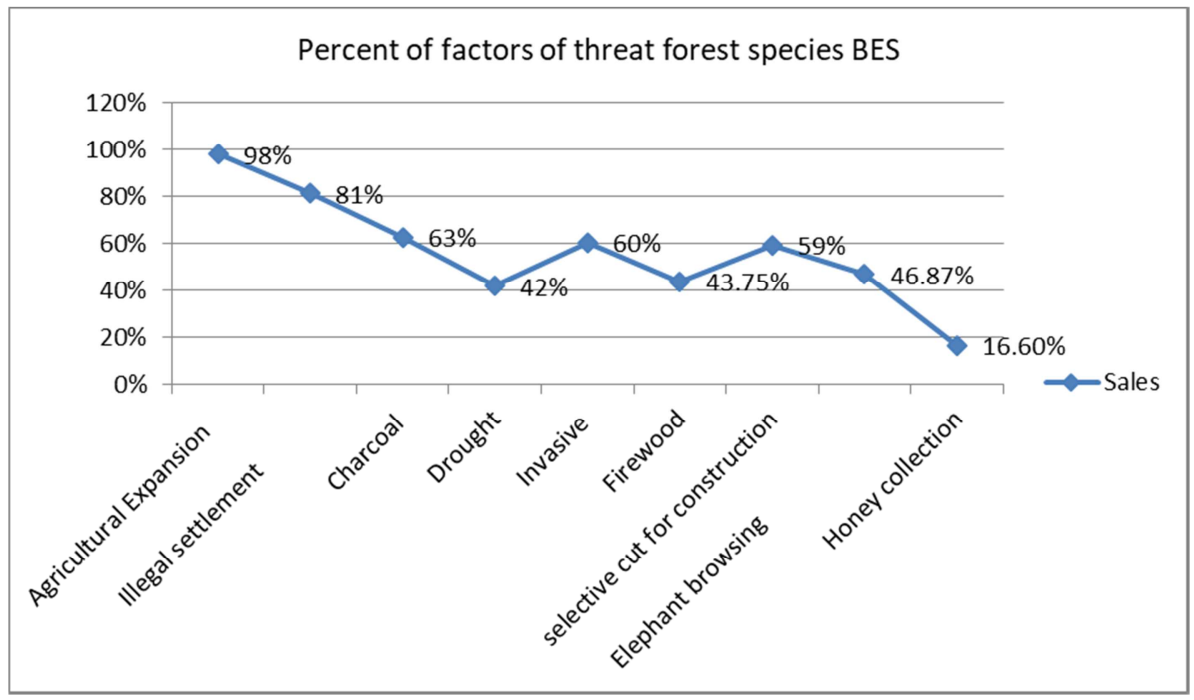

Figure 5. Percentage of factors threat BES.

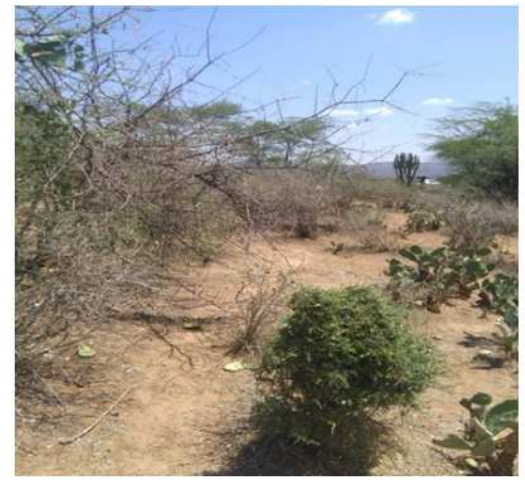

A. Forest Species Dried by Drought

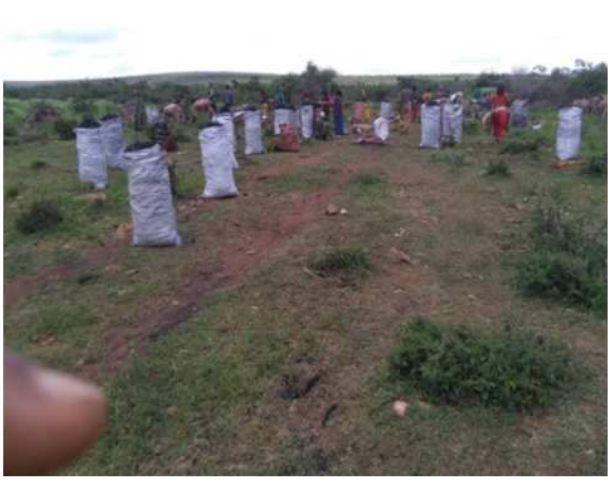

B. charcoal production

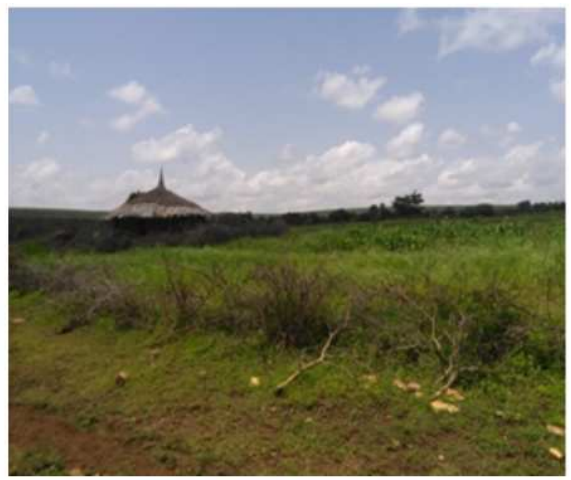

C. Over grazing by animal
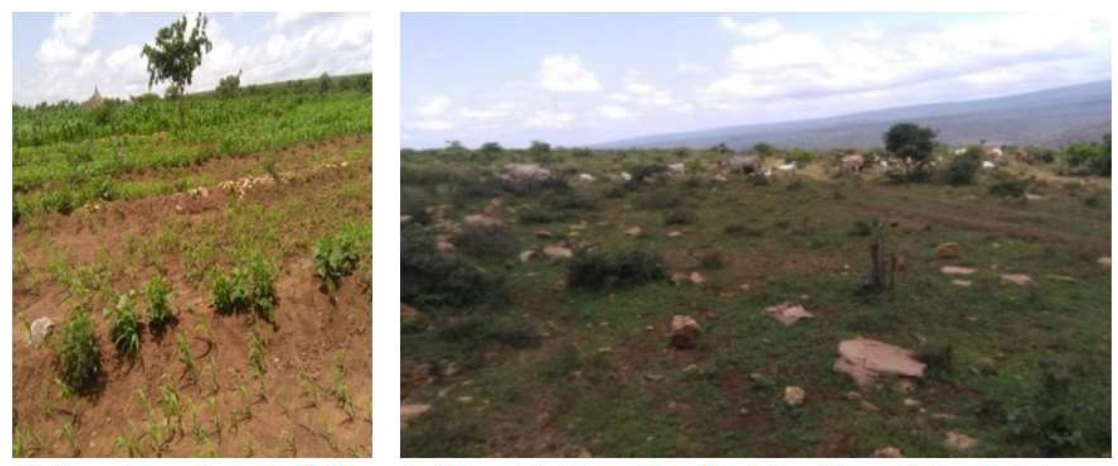

D. Forest area destructed for agriculture E. Firewood collected and brought to market

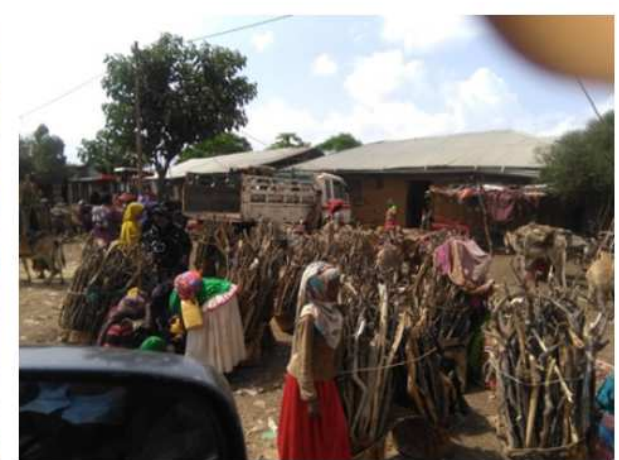

F. Herds of Camel come for grazing

Figure 6. Picture recorded during field as factor of threat (photo: Tahir Abdala). 


\section{Conclusion and Recommendations}

The study was conducted on proximity adjacent six kebele of BES. From this study 61 forests plant species were identified. According to this all identified plant species level of threatened plant species were determined by knowledge of local community. Among all determined plant species 38 $(45.7 \%)$ species were categorized under highly threatened, 23 $(38 \%)$ species were categorized under medium threatened and $10(16 \%)$ species were categorized under low/least threatened.

The study revealed 11 major factors of threat and among this agricultural exposition held the $1^{\text {st }}$ rank followed by Illegal settlement and Over Grazing as $2^{\text {nd }}$. Charcoal making and tree cutting the $3^{\text {rd }}$ factors fallowed by invasive. In addition currently, investment is $5^{\text {th }}$ factors fallowed by Elephant browsing held as $6^{\text {th }}$ factors followed by Construction, Firewood and Honey collection held the rank $7^{\text {th }}, 8$ th and $9^{\text {th }}$ respectively. A. tortilis and $A$. seyal seem to be widely used and important. These resources are still widely available, but ecological (frequent and prolonged drought conditions) and human-related factors (charcoal production, clearance for agriculture and unsustainable utilization) are potential threats to their future availability. Generally, agricultural expansion, illegal settlement, Charcoal production, invasive species, investment and selective cut for construction, Elephant browsing, fire wood, drought, and Honey collection were the main threats in the sanctuary.

Table 5. Community and focal person perception on challenges of conservation of biological resources in BES (NCR-96).

\begin{tabular}{|c|c|c|c|c|c|}
\hline \multirow{3}{*}{ No } & \multirow{3}{*}{ Challenges } & \multicolumn{4}{|c|}{ Column3 } \\
\hline & & \multicolumn{2}{|l|}{ Yes } & \multicolumn{2}{|l|}{ No } \\
\hline & & No & $\%$ & No & $\%$ \\
\hline 1 & Lack of community participation for conservation & 76 & $79.1 \%$ & 20 & $20.8 \%$ \\
\hline 2 & Lack of Awareness & 80 & $83.33 \%$ & 16 & $16.66 \%$ \\
\hline 3 & Lack of community Incentive & 87 & $90.62 \%$ & 9 & $9.3 \%$ \\
\hline 4 & Lack of alternative job & 90 & $93.75 \%$ & 6 & $6.25 \%$ \\
\hline 5 & Lack of strong regulation and relation of park administration with community & 85 & $88.54 \%$ & 11 & $11.45 \%$ \\
\hline 6 & Existence of park between two region & 65 & $67.70 \%$ & 31 & $32.29 \%$ \\
\hline 7 & Lack of clear boundary demarcate & 57 & $59.37 \%$ & 39 & $40.62 \%$ \\
\hline 8 & Dependence of local community on agriculture & 68 & $70.83 \%$ & 28 & $29.16 \%$ \\
\hline
\end{tabular}

Eight major challenges were identified for current conservation BES. Among them, Lack of alternative job as the major challenge as responded by communities 90 (93.75\%) followed by Lack of community Incentive when elephant browsing and damage local crop 87 (90.62\%) and Lack of strong regulation and relation of park administration with community was the third factor as responded by $85(88.54 \%)$. The current study suggest that important intervention is necessary to conserve threatened plant species in BES. In order to alleviate the existing problem, the authors forwarded the following recommendation:

1) Rehabilitation by plantation especially the indigenous multi-purpose tree species that are highly threatened but still available in the valley should be given emphasis;

2) Alternative livelihood has to be created for surrounding local community to reduce agricultural expansion;

3) Awareness creation program has to be done to the local community about the importance of protected area conservation and devise a mechanism by which human impacts can be minimized through discussion and consultation with the local people;

4) Provision of incentives for local communities to support protected areas;

5) In collaboration, protected area staff, local people, governments and the general public should:

a) Carry out further studies on the patterns of ecosystem functioning, biology and ecology of the key stone species to be able to restore the composition and structure of the forest;

b) Enforcement of the rule of law with respect to protection.

6) Mechanism should be devised by respective organization through which communities participate in every aspect of protected area management such as planning;

7) Increasing cooperation and collaboration between the two regional state that bound the sanctuary for effective conservation of the sanctuary as a general and its biological diversity particularly;

8) Participation of communities on decision making process may be necessary so that they perceive the own the resource;

9) Revising government management plan may be necessary to identify gaps.

\section{Declarations}

\section{Competing Interests}

The authors declared that they have no competing interests.

\section{Availability of Data and Material}

The recorded raw data used for analysis and supplementary information files is available at the author's hand and within the article. 


\section{Acknowledgements}

We would like to acknowledge the project entitled "enhanced management and enforcement of the Ethiopian protected area estate" for financial support. Furthermore, we want to thank local people in general and informants in particular for their great help and shared their knowledge and time. Finally, we want to thank Ethiopian Biodiversity Institute.

\section{References}

[1] Alexiades M., (1996) "Collecting ethnobotanical data. An introduction to basic concepts and techniques," in Selected Guideline for Ethnobotanical Research: A Field Manual, M. Alexiades and J. W. Sheldon, Eds., pp. 58-94, Botanical Garden, NewYork, NY, USA, 1996.

[2] Allen-Rowlandson, T. S. (1990). Elephant survey in Ethiopia. A report submitted to the Ethiopian Wildlife Conservation Organization. Addis Ababa. pp. 19.

[3] Anteneh Belayneh (2006). Floristic description and Ethnobotanical study of the natural vegetation in Babile Elephant Sanctuary, Ethiopia. M.Sc. Thesis, Addis Ababa University, Ethiopia.

[4] Anteneh Belayneh, and Sebsibe Demissew (2011). Diversity and Population Structure of Woody Species Browsed by Elephants in Babile Elephant Sanctuary, eastern Ethiopia: an implication for conservation.

[5] Augustine, D. J. and McNaughton, S. J. (2004). Regulation of shrub dynamics by native browsing ungulates on East African rangeland. J. Appl. Ecol. 41: 45 - 58 .

[6] Azene Bekele, Birine, A., and Tengas, B. (1993). Useful trees and shrubs for Ethiopia: Identification, Propagation and Management for Agricultural and Pastoral Communities. Regional Soil Conservation Unit SIDA, RSCU, Nairobi, Kenya. 484 pp.

[7] Barnest, R. F. W., Craig, G. C., Dublin, H. T., Ovelion, G., Simons, W., and Thouless, C. R. (1999). African elephant Database 1998. IUCN/SSC Africa Elephant Specialist Group. IUCN, Gland, Switzerland and Cambridge, UK.

[8] CBD (Convention on Biological Diversity). 2010. The 10th Meeting of the Conference of Parties (COP 10): Decision X/2 on Strategic Plan for Biodiversity, Geneva, Switzerland.

[9] Cotton C. M., Ethnobotany, Principles and Applications, John Wiley \& Sons, Chichister, UK, 1996.

[10] Dejene W. Sintayehu and Awol S. E, 2020. Consequences of Temporal Land Cover Changes on Ecosystem Services in Babile Elephant Sanctuary, Eastern Ethiopia. East African Journal of Sciences (2020). Volume 14 (1) 39-50.

[11] Feyera Senbeta and Demel Teketay (2003). Diversity, Community type and population structure of woody species in Kimphee Forest: a unique Natural reserve in Southern Ethiopi. Eth. J. Bioi. Soc. 2 (2): 169-187.

[12] Haslett, J., Berry, P., Bela, G., Jongman, R. G., Pataki, G., Samways, M. and Martin, Z. 2010. Changing conservation strategies in Europe: a framework integrating ecosystem services and dynamics. Biodiversity and Conservation, 19: 2963-2977.
[13] http://www.ewca.gov.et, accessed May 2011.

[14] IUCN, 1990. United Nations list o/national parks and protected areas. IUCN, Gland, Switzerland.

[15] Kefyalew T. E, 2008. Integrated Assessment of ecosystem services and stakeholder analysis of Abijata-Shalla Lakes National Park, Ethiopia. MSc Thesis in Environmental Sciences. Wageninge University.

[16] Kiringe J. W and Okello M. M, 2007. Threats and their relative severity to wildlife protected areas of Kenya. APPLIED ECOLOGY AND ENVIRONMENTAL $\begin{array}{lrrr}\text { RESEARCH } & 5 & \text { (2): } & 49-62 .\end{array}$ http://www.ecology.uni-corvinus.hu · ISSN 15891623 2007, Penkala Bt., Budapest, Hungary.

[17] Kumssa T, Bekele A (2014) Attitude and Perceptions of Local Residents toward the Protected Area of Abijata-Shalla Lakes National Park (ASLNP), Ethiopia. J Ecosys Ecograph 4: 138. doi: $10.4172 / 2157-7625.1000138$.

[18] Lopoukhine, M., Crawhall, N., Dudley, N., Figgis, P., Karibuhoye, C., Laffoley, D., Miranda, Londoño, J., MacKinnon, K. and Sandwith, T. 2012. Protected areas: providing natural solutions to 21 st Century challenges. Surveys and Perspectives Integrating Environment and Society, 5: 1-10.

[19] Martin G. J., Ethnobotany: A Method Manual. A "People and Plants" Conservation Manual, Champman and Hall, London, UK, 1995.

[20] Mekuria Aragaw, Demel Teketay and Olsson, M. (1999). Soil seed flora, germination and regeneration pattern of woody species in Acacia woodland of Rift Valley in Ethiopia. J. Arid. Environ. 43: 411-435.

[21] Meseret Ademasu (2006). History and status of the population of African elephant (Loxodonta africana, Blumenbach, 1797) and Human-elephant conflict in Chebera-Churchura National Park, Ethiopia. M.Sc. Thes es, Addis Ababa University, Ethiopia.

[22] Mohr, P. A. (1964). The geology of Ethiopia. University College of Addis Ababa Press, Ethiopia. 268 pp. NMSA, 2005. National Meteorological Service Agency Data from 1965 to 2005.

[23] Palomo, I., Martín-Lopez, B., Alcorlo, P. and Montes, C. 2014 Limitations of protected areas zoning in Mediterranean cultural landscapes under the ecosystem services approach. Ecosystems, 17: 12021215.

[24] Rands, M. R. W., Adams, W. M., Bennun, L., Butchart, S., Clements, A., Coomes, D., Entwistle, A., Hodge, I., Kapos, V., Scharlemann, J. P. W., Sutherland, W. J. and Vira, B. 2010. Biodiversity conservation: challenges beyond 2010. Science, 239: 1298-1303.

[25] Shibru Tedla (1995). Protected areas management crisis in Ethiopia. Walia 16: 17-30.

[26] Smith, P., Gregory, P. J., van Vuuren, D., Obersteiner, M., Havlik, P., Rounsevell, M., Woods, J., Stehfest, E. and Bellarby, J. 2010. Competition for land. Philosophical Transactions of the Royal Society of Biological Sciences B, 365: 2941-2957.

[27] Stephenson, J. P. (1976). Report on the Harar elephant dilemma. Addis Ababa, Ethiopia. 22pp+Maps. 
[28] Steyn, A. and Stalmans, M. (2001). Selective habitat utilisation and impact on vegetation by African elephant within a heterogeneous landscape. Koedoe 44 (1): 95 - 103.

[29] Tahir Abdala, Girma Eshetu, Abebe Worku. A Participatory Assessment of Forest Biodiversity Resources and Level of Threat in Hararge Area, Eastern Ethiopia. International Journal of Science, Technology and Society. Vol. 5, No. 4, 2017, pp. 67-73. doi: 10.11648/j.ijsts.20170504.13.

[30] Tahir Abdala, Yeneayehu Fenetahun. Review on Floristic Diversity and Threated Plant Species in Babile Elephant Sanctuary in East Hararge, Ethiopia. American Journal of Environmental Science and Engineering. Vol. 1, No. 1, 2017, pp. 1-6. Doi: 10.11648/j.ajese.20170101.11.

[31] Tamene S. B, 2020. Assessment of woody species diversity, key drivers of deforestation and community perception; the case of Hotessa Forest, Bensa Woreda, Sidama Zone, Southern Ethiopia. African Journal of Plant Science. Vol. 14 (5), pp. 172-182, May 2020 DOI: 10.5897/AJPS2020.1988 Article Number: 750620963647 ISSN 1996-0824 Copyright (C) 2020 Author(s) retain the copyright of this article http://www.academicjournals.org/AJPS

[32] United Nations Environment Programme (2003). World Conservation Monitoring Centre (UNEPWCMC). World
Database on Protected Areas (WDPA) Version 6. Compiled by the World Database on Protected Areas Consortium. Cambridge, U. K.

[33] Yirmed Demeke (1997). The status of the African elephant (Loxodonta africana) in Ethiopia. Walia. 15: 23-32.

[34] Yirmed Demeke and Afework Bekele (2000). Population estimate and threat to elephants Loxododonta africana (Blumenbach, 1797) in Mago National Park, Ethiopia. Trop. Zool., 13: 227-237.

[35] Yirmed Demeke, Marilyn, B. R, Roger, V. S. and Richard, F. B., (2006). The undisclosed facts about the relic elephant population in the Horn of Africa. Proceedings of Biological Society of Ethiopia, 16th annual conference and workshop. 13 pp.

[36] Watson, J. E. M., Dudley, N., Segan, D. B. and Hockings, M. 2014. The performance and potential of protected areas. Nature, 254: 17-25.

[37] Zelealem Tefera (1995). Community participation in the conservation of natural habitat in Menz area of North Shoa. Proceedings of participatory wildlife management workshop. Ministry of Natural Resource Development and Environmental Protection (MNRDEP) and FARM Africa, Addis Ababa, Ethiopia. 